\title{
Pragmatic Explicitation Strategy in Rendering of Tayeb Salih's Season of Migration to the North into English: A Socio-cultural Study
}

\author{
Dr.Ali Albashir Mohammed Alhaj \\ King Khalid University, Dhahran Aljanoub ,College of Sciences and Arts ,Department of English \\ Dr. Sabah Mohamed Abbas Hamza \\ King Khalid University, Dhahran Aljanoub ,College of Sciences and Arts , Head, Department of English
}

\begin{abstract}
The current paper aims to study critically how the translator(Denys Johnson-Davies) has employed explicitation strategy in rendering the novel of Tayeb Salih's" Season of Migration to the North into English". The objective of the study is to examine the usage of explicitation strategy by the intended translator in rendering the novel from Arabic into English. The novel has many complicated symbols and many literary and thematic techniques such as the reference to the Nile, the sand, the palm tree which may pose some lexical and cultural challenges for the translator to reproduce the text into the target language. The data to be analyzed here is a set of selected expressions chosen randomly from various pages of the intended novel. The selected data were then classified on the basis of reasons for which explicitation strategy was used and the effectiveness of explicitation strategy in rendering some cultural expressions into English. The result of the study reveals that the translator (Denys Johnson-Davies)has resorted to some types of explicitation strategy categorized by Klaudy. They are : the obligatory, optional and pragmatic explicitation such as (addition ,substitution, recasts and narrowing ( specification).
\end{abstract}

Keywords: Explicitation Strategy, symbols, challenges, pragmatic, addition, substitution

DOI: $10.7176 / J L L L / 57-05$

Publication date:June $30^{\text {th }} 2019$

\section{Introduction:}

Armed with their linguistic and extra linguistic knowledge, the translators shoulder the challenges of rendering, a complicated process involving numerous steps, procedures and strategies, for instance, using explicitation strategy in rendering of Tayeb Salih's Season of Migration to the North into English. Indeed, some parts of this book is dense and difficult, hence, the translator sticks to the more literal translation, or after a thorough analysis of its meaning, presented the meaning more freely with consideration of the source form by using explicitation strategy. Thus, many factors come into play in the choice of explicitation strategy., including the nature of the source text( Arabic version), the function of the translation, and even the differences between the source language( Arabic)and the target language( English).These, in turn, influence the translation product ..

Given the number of factors involved in the production of the source text, the author's intended message may not be textually realized as clearly or as exactly as s/he may wish. However, it is on the message as realized in the source text and not on what the author may have intended to say that the translator works. The translator, who inevitable has a different background from the original author, has to grasp fully the source text message in order to translate it as the eminent translator Denys Johnson-Davies did in his rendition of Tayeb Salih's novel Sean of Migration to the North. According to Jill Neville, the Sunday Times ,(n.d):

Salih is a masterly Sudanese writer with an oceanic almost Jungian vision, produced and yet entirely matter of fact, without a false note or wrong emphasis. Yet , he is a Sudanese so soaked in European culture that he can grasp all the nuances and edge in the life in London in, for example, the 1920s, with total authority.

\section{Literature review}

2.1The Themes of Tayeb Salih's novel Season of Migration to the North: At A Glance

Thematically, the title provides a clue to the theme and meaning of the novel under the study. The theme is the moral, intellectual, aesthetic, spiritual, mental and physical migration or displacement of. Both M. Saeed and the narrator and their final self -annihilation

The essential theme of the novel resolves around the character of an infra dig culture. It depicts the behavior of a lost generation. The theme and the content of the novel suggests an inner adoption of another cultural identity and stress the migration to another culture as performed by M.Saeed, the narrator.

The theme shows that the cultural migration made M.Saeed spiritually bankrupt. It also shows the narrator as a displaced and uprooted figure from his culture. and as a man who was loaded the doses of migration. $\mathrm{He}$ 
could neither depart nor remain .

Finally, the theme of Tayeb Salih's novel Season of Migration to the North has been served and sustained throughout the novel by many literary and thematic techniques such as the reference to the Nile, the sand, the palm tree, etc. They served to elaborate the theme and stood as sources of other thematic variations of the same theme.( Alnoor, 2001,p.221)

\subsection{Concept of explicitation}

At the outset, according to most scholars, who empirically investigate explicitation strategy and considers it as a great tendency in translation, amongst them is Jimenez-Crespo (2011) who argues that:

"explicitation has long been considered as a tendency in translation and this approach is in parallel with the definition proposed by Mona Baker (1996)" who says "an overall tendency to spell things out rather than leave them implicit"(P.176).) retrieved 0n $17 / 5 / 2019$ form https://www.iasj.net/iasj?func $=$ article\&aId $=118083$ )

According to Vinay and Darbelnet, (1958/1995,p. 342):

'explicitation is a stylistic translation technique which consists of making explicit in the target language what remains implicit in the source language because it is apparent from either the context or the situation'.

On his turn, the eminent Hungarian scholar Blum -Klaudy(2011,p.106) defines explicitaion as : a technique of making explicit in the target text information that is implicit in the source text

Klaudy also proposes the following four types of explicitation in translation: (a)Obligatory Explicitation, (b) Optional Explicitation(c) Pragmatic Explicitation(d) Translation-inherent explicitation.

On the other hand, some translation scholars such as Nida who does not use the terms 'explicitation'. But he deals with the main techniques of adjustment used in the process of translating, namely additions, amplification , reduction, diffusion and condensation .

\subsubsection{Concept of Pragmatic explicitation}

Pragmatic explicitation is dictated by differences in cultural and/or world knowledge shared by members of the source and target language communities.

Klaudy (2008)suggests that translators often need to add linguistic items in order to explain a concept that is culture specific to the source -language. For example names of places, items of food which are well known to the community of the source language may mean nothing to the community of the target language unless an explanation is included in the translation.(p.68).

\subsection{Addition}

Dickens (2002,p.56) defines this strategy " translation in which something is added to be the target text which is not present in the source text" ,such a strategy, however, often attempts to insert additional elegant-sounding words or phrases into a TT to counter balance any weaknesses that might creep in. Furthermore, in some cases the text involves particular features such as symbolism or symbolic language, which expresses concepts likely to be inaccessible to the reader. Here it is the translator's job to make these elements as comprehensible as possible. Addition or even expanding the TL may produce as closely as possible the original effect produced in the SL.

Matthiessen (1999,p.89) stresses the importance of not allowing any explanation to lead to divergence from the style of the original, noting the advantage of using short adjectival or adverbial phrase rather than notes or additional explanatory sentence. However, when more detail is required, a competent or skilled translator may succeed incorporating it unobtrusively. On his turn Nida $(2002, p .277)$ speaks of addition whenever the target text contains more linguistic material than its source. However, he stresses that only those additions" may legitimately be incorporated into a translation " ( Nida,2002, p.228)., that do not change the semantic content of the message, rather make information explicit that is implicitly present in the source text..Thus, translating a passive clause as an active clause or shifting the word class from event noun to verb might make it grammatically necessary to insert certain participants

Addition takes more than one form and is used for different purposes depending on the context and style of the translator. Ali (1983, p.8), for instance, finds brackets useful to give elucidation, differentiated or implied , extended meanings of words, or to fill elliptical gaps. The following excerpts exemplify the various categories of explicitation:

\subsubsection{First category: Addition of verbs}

\begin{tabular}{|c|c|}
\hline Source text & Target text \\
\hline $\begin{array}{l}\text { The unsuitability of a teacher for the position of } \\
\text { teaching means }\end{array}$ & و يعني عدم ملائمة المعلم لوظيفة التعليم التي يعمل فيها \\
\hline
\end{tabular}


2.3.2Second category: Addition of nouns

\begin{tabular}{|c|c|}
\hline Source text & Target text \\
\hline French language skills & شرط التمتع بمهار ات اللغة الفرنسية \\
\hline \multicolumn{2}{|l|}{ 2.3.3Third category: Addition of adjective } \\
\hline Source text & Target text \\
\hline She should wear tumble/coat bullets & يجب عليها ارتداء معطف واق من الرصاص \\
\hline \multicolumn{2}{|l|}{ 2.2.4Fourth category: replacing pronouns with nouns: } \\
\hline Source text & Target text \\
\hline $\begin{array}{l}\text {... an agreement of four originals, one to be handed } \\
\text { for the witness }\end{array}$ & اتفاقية من أربعة أصول, يقدم ألأصل ألاول \\
\hline \multicolumn{2}{|c|}{ 2.3.5 Fifth category: addition of referential clitics(referential pronoun) } \\
\hline Source text & Target text \\
\hline $\begin{array}{l}\text { Students should wear school uniform while on } \\
\text { examination duty }\end{array}$ & يجب على الطلاب ارتداء الزى المدرسي أثناء تأديتهِ امتحاناتهِ \\
\hline \multicolumn{2}{|c|}{ 2.3.6Sixth category: recasts (adding a combination of a noun and adjective, using prepositions) } \\
\hline Source text & Target text \\
\hline Hospitalization & إِذخالَ أو دُخولُ المُسْنَشَتْفى \\
\hline Transcript & /دفتر علامات الطالب/ صورة طبق الأصل \\
\hline Deans reporting to..... & العمداء تحت رئاسة \\
\hline
\end{tabular}

\subsection{Substitution}

It is used when a word in a source text does not have equivalent in the target text... As Taylor,(1988,p.52) opines:

The antithesis of equation, to return to Malone's terminology, is substitution, in which a translation is used that may bear little or no morphological or semantic relation to the source text. There is ' equivalent ' as such.

\subsubsection{Examples of substitution}

\begin{tabular}{|c|c|}
\hline Source text & Target text \\
\hline Marital status & الحالة الاجتماعية \\
\hline Educational certificate & شهادة المؤ هل العلمي \\
\hline
\end{tabular}

2.5 Narrowing ( specification).In this explicitation feature the word of the target text is narrower in meaning, than the word of the source text,( Klaudy, 2011).for example:

\begin{tabular}{|c|c|}
\hline Source text & Target text \\
\hline $\begin{array}{l}\text { A.Home address and rotary phone number } \\
\text { B. Mobile Number }\end{array}$ & 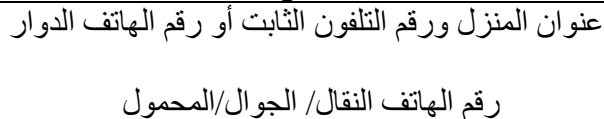 \\
\hline
\end{tabular}

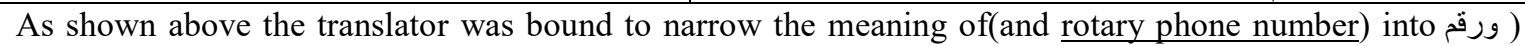
(التلفون الثابت أو رقم الهاتف الدوار) (land line phone number) because it was followed by the(Mobile Number, enforcing him to distinct and draw a line of demarcation between the two numbers.

\section{Objectives}

The study aimed to:

a. investigate the role of pragmatic explicitation strategy in rendering of Tayeb Salih's Season of Migration to the North into English .

b. explore how pragmatic explicitation strategy played a role in leading to longer translation.

c. give corroborating evidence of pragmatic explicitation as required strategy used in rendering English/ Arabic/ texts in general and literary text in particular (Tayeb Salih's Season of Migration to the North into as an example).

\section{Research Questions}

To meet the stated objectives, the following research questions were raised:

a. to what extent does pragmatic explicitation strategy lead to longer translation?

b. does Denys Johnson-Davies as the eminent and professional translator go about pragmatic explicitation differently from other translator or non-professionals? 


\section{Methodology}

\subsection{The Context of the Study}

In the current study, the researcher used descriptive qualitative method which 'involves data collection procedures that result primarily in open-end, non -numerical data which is then analyzed by non-statistical method'(, Dornyi, 2007,p.24). Also, it tries to analyze how the procedures and strategies adopted by the eminent translator Denys Johnson-Davies in his attempt to render Tayeb Salih's Season of Migration to the North into English: and also to assess and evaluate his rendition of this novel

\subsection{Data Analysis}

The data will be analyzed subjectively or qualitatively in the main. That is, the examples will be described by category as grammatical, lexical, stylistic, explaining the type of error..Also the study aims at exploring explicitation strategy employed by the eminent translator Denys Johnson-Davies while rendering Tayeb Salih's Season of Migration to the North into English

\subsection{Research Instrument}

Research instrument is very important to obtain the result of a study, it is a set of methods which are used to collect the data. The researcher is the main instrument of the study. Cresswell (1994,p.145) states that the qualitative research is the primary instrument for the data collection and data analysis. Besides that, the researcher spent a great deal of time in reading Arabic and English translation of Tayeb Salih's Season of Migration to the North for intention to study the same of phenomena of explicitation technique employed by the translator while translating this literary text from Arabic into English.

\subsection{Procedure}

One useful methodological procedure for researching pragmatic explicitation in rendition of Tayeb Salih's "Season of Migration to the North" would be to scam a corpus of translated texts into English and note the occurrence of any of these features regardless of the source language(Arabic language). The categories identified would then be compared with a comparable corpus of original writing in the target language specified. This kind of data may at a later stage be run against similar data obtained when different target language are used.

The analysis of the data proceeded as follows. The researcher carefully reads through all corpus texts( both Arabic and English version of Tayeb Salih's Novel " Season of Migration to the North" multiple times, identifying all pragmatic explicitation according to the criteria laid down in the following categories . Categories were formally classified as additions, substitutions, and omissions, depending on the type of operation that Denys Johnson-Davies has employed (a) addition of verbs, (2) addition of nouns (3) addition of adjective(4) replacing pronouns with nouns(5) addition of referential clitics (referential pronoun)(6) recasts (adding a combination of a noun and adjective , using prepositions) (see Section 2.2 for examples). Moreover, the syntactic category of the explicitated/implicitated material was determined (noun, pronoun, proper name, adjective, adverb, connective, etc)

\subsection{Data Collecting and sampling}

\subsubsection{Existing Practices in the Translation Tayeb Salih's Season of Migration to the North into English}

The real objective of the current study is to investigate the adequacy of employing explicitation while rendering Tayeb Salih's Season of Migration to the North from Arabic into English and to answer the basic question :' to what extent does pragmatic explicitation strategy lead to longer translation: '. Some linguists state that this question can only be answered if one draws a clear demarcation line between necessary explicitation and redundant explicitation.

6.Pragmatic Explicitation Strategy in the Translation of "Tayeb Salih's Season of Migration to the North" Example (1)

\begin{tabular}{|c|c|c|}
\hline ST & TT & $\begin{array}{c}\text { Feature of pragmatic } \\
\text { explicitation strategy }\end{array}$ \\
\hline $\begin{array}{c}\text { an wajadatani qayimana } \\
\text { baynahum }\end{array}$ & When at last found myself standing amongst & $\begin{array}{c}\text { Addition( idiom and } \\
\text { phrase) } \\
\text { them }\end{array}$ \\
Recasts \\
\hline
\end{tabular}

\section{Discussion}

Denys Johnson-Davies's rendition for (an wajadatani qayimana baynahum)(أن وجتني قائما بينهم) which seems accurate than the ST" Source Text" because he adds the idiom ( at last) which maintains syntactic contextuality through an anaphoric reference and makes the meaning more acceptable and meaningful for the receptor of $*\{$ All references to this text are from this editions and are quoted by page numbers in parenthesis the English 
language. Also, The differences in the syntactic and/or semantic structure between the source and the target language lead the translator to add some grammatical items as in the above-mentioned example.

Example (2)

\begin{tabular}{|c|c|c|}
\hline ST & TT & $\begin{array}{c}\text { Feature of } \\
\text { pragmatic explicitation } \\
\text { strategy }\end{array}$ \\
\hline $\begin{array}{c}\text { وفرغ أبي من صلاته وأوراده 'abi min salatah wa'awradih } \\
\text { wafaragh 'abi }\end{array}$ & $\begin{array}{l}\text { My father, having finished his } \\
\text { prayers and recitations from the } \\
\text { Koran.(S.M.N,p.) }\end{array}$ & $\begin{array}{c}\text { Addition } \\
\text { Substitution }\end{array}$ \\
\hline
\end{tabular}

\section{Discussions}

Denys Johnson-Davies's rendition for (wafaragh 'abi min salatah wa'awradih وفرغ أبي من صلاته وأور اده (Sadds some grammatical items by changing singular (صلاته) in the source text (ST) into plural nouns( prayers in the target text (TT) by doing so , the translator uses pragmatic explicitation strategy category addition of referential clitics(referential pronoun). Hence, his translation for for (wafaragh 'abi min salatah wa'awradih وفرغ أبي من is more appropriate and accurate.

The translator opted to render(wa'awradahoو أواردn ( recitation from the Koran) but in this type of pragmatic explicitation strategy the translator may resort to one pragmatic explicitation strategy of footnote or transliteration strategy to explain the Arabic lexis((wa'awradahoوأو ) in order to overcome the differences in the text building or in the stylistic preferences between languages .For better sense of Arabic lexeme, The better solution is that: the translator may choose to add the following elements to his renditions, and use the following suggested footnote and transliteration to clarify the Arabic lexeme(wa'awradaho :

أوراد $\quad$ awrad specified time of day or night devoted to private worship ( in addition to the five prescribed prayers), a section of the Holy Qur'an recited on this occasion(A Dictionary of Modern Written Arabic, 2006,p.1060)

Such explication and expansion add to the comprehension, and the translator remains faithful to both source text(ST) and target text(TT). For the younger receptor of the English language, archaism is really problematic, so contemporary usage is rather a better for the Arabic lexeme( Koran). Also, the translator puts the letter (k) in the object word 'kur'an', which is not understood with reference to both Arabic and English alphabets. This may result in a confused pronunciation, for example, if someone spells the word ( book) as (booq) or ( quest) as ( kuest), it will certainly not be appreciated by contemporary English reader.( Khan ,2009,p.144) . One-word substitution for Qu'anic name is needed and explication is inevitable. Archaism needs to be attended prudently by using pragmatic explicitation strategy ( substitution category) to avoid misrepresentations of the source text (ST).

Example 3

\begin{tabular}{|c|c|c|}
\hline ST & TT & $\begin{array}{c}\text { Feature of } \\
\text { pragmatic explicitation } \\
\text { strategy }\end{array}$ \\
\hline 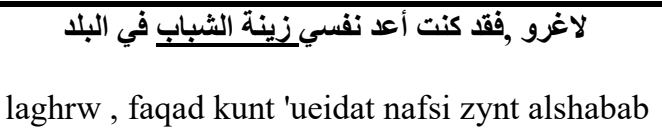 & $\begin{array}{l}\text { No wonder, for I used to regard } \\
\text { myself as the outstanding young man } \\
\text { in the village (S,M.N,p. }\end{array}$ & Addition \\
\hline
\end{tabular}

\section{Discussion}

The translator fronted the sentence(fqad kunt 'aead nafsiin(فق كنت أعد نفسي),)with the conjunction device (for) which is an addition and more appropriate in the light of the cultural and co-textual context of the novel. Also, the translator may have resorted to show more emphasis on the intended meaning. Here, the conjunction [for] is more emphatic and makes the communication in TT more forceful which will certainly be appreciated by contemporary English reader and the receptor of English language as well..

The translator here added two adjectives the first one (outstanding) may be as an attempt to prepare the English receptor to be ready to accept what follows and later strengthen this with another adjective( young) to render the noun phrase (zynt alshabab (زينة الثباب) .Redundancy is obvious in the target text but it is known to be a syntactic feature of the English language itself. Denys Johnson-Davies's syntactic expansion gives quite simple and more effective clue to the receptor of the target text. The pragmatic explicitation strategy (addition) remaining faithful to the content of the novel in Source language (SL),results in semantic simplicity, which is essential for better comprehension . 
Example 4

\begin{tabular}{|c|c|c|}
\hline ST & TT & $\begin{array}{c}\text { Feature of } \\
\text { pragmatic explicitation strategy }\end{array}$ \\
\hline 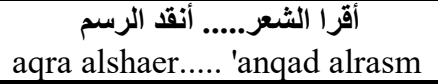 & $\begin{array}{c}\text { I would read poetry...... discuss } \\
\text { paintings (S.M.N.p.38) }\end{array}$ & Substitution \\
\hline
\end{tabular}

\section{Discussion}

In this type of pragmatic explicitation strategy the translator may resort to the (substitution)strategy to render the verbal phrase(..... 'anqad alrasma أنقا الرسم) . Here, translator used the lexeme (discuss) instead of the correct lexeme ( criticize) which gives the different meaning but grammatically correct(form). The rendition is not so clear as is needed by an average receptor of the content of the novel. In this example. Denys Johnson-Davies adheres to the formal equivalence rather than the dynamic equivalence. It means that, the translator adheres to the (form) rather than the (content) . The latter is more important than the former if the translator maintains content of the novel through dynamic equivalence. A significant style of subsisting the verb( discuss) in the rendering of the verbal phrase (..... 'anqad alrasm أنقد الرسم) is so tortuous and full of twists.

To sum up ,in the expression (..... 'anqad alrasm أنقد الرسم) the word(discuss) is not important, instead the lexeme(criticize) itself is important, so a better rendition and communication which really communicates the better sense of the novel and certainly add to the comprehension of an average receptor of the English version of the novel .

Example 5

\begin{tabular}{|c|c|c|}
\hline ST & TT & $\begin{array}{c}\text { Feature of } \\
\text { pragmatic explicitation strategy }\end{array}$ \\
\hline كانت ليلّة قائظة من ليالي شهر يوليو & $\begin{array}{c}\text { Addition } \\
\text { Literal translation }\end{array}$ \\
\hline
\end{tabular}

\section{Discussion}

The use of abstract word( adverb) of manner ( steamingly hot night ) by Denys Johnson-Davies's is certainly confusing for the receptor as the rendering of the expression كانت ليلة قائظة (kanat laylat qayiza) lacks cohesion. The suggested rendering for the same expression (Sweltering night ليلة قائظة) by the researcher is appropriate rendering in the co-textual context which maintains the lost cohesion as compared to the former rendering of the adverbial phrase(( steamingly hot). This suggested rendering is significant and distinctive as compared to Denys Johnson-Davies's rendered expression which lacks intensity and has a grammatical ambiguity. (Sweltering night ليلة قايظة) is pragmatic explicittioan strategy used by the researcher adds more vivid and efficient communication and comprehension even of an average receptor. The researcher's rendition seems more accurate and proper rendition than Denys Johnson-Davies's rendering who used the expression (steamingly hot night) instead of (Sweltering night), so, his rendition gives no specific identification, hence, confusing and complex communication.

Example 6

\begin{tabular}{|c|c|l|}
\hline ST & TT & $\begin{array}{c}\text { Feature of } \\
\text { pragmatic explicitation } \\
\text { strategy }\end{array}$ \\
\hline وحين يبين الخيط الأبيض من الخيط الأسود نقول & And when the white thread is distinguished & $\begin{array}{c}\text { Narrowing } \\
\text { ( specification }\end{array}$ \\
\hline
\end{tabular}

\section{Discussion}

As shown above, the translator was bound to narrow the meaning of الخيط الأبيضyubayin alkhayt al'abyad into "the white thread". Here the translator omitted the lexeme (of dawn) in the target text, T.T,Hence, his rendition is inaccurate and inappropriate. In this context the researcher suggests the following alternative translation "And when the white thread of dawn becomes distinct to you from the black thread [of night]And when the white thread of dawn becomes distinct to you from the black thread [of night]

Denys Johnson-Davies put in the begriming of his renditions the relational word and the discourse marker' when' to indicate the narrative sequence of the story, and at the same time, it denotes that something has already happen and its details are being narrated later on.

The use of the relational word' and 'in the beginning of the same rendition is appropriate.

\section{Conclusion}

\subsection{Summary of the Findings}

On the bases of the theoretical part and data analysis, the current study has come up with the following conclusions:

1. The translator (Denys Johnson-Davies)has resorted to some types of explicitation strategy categorized 
by Klaudy. They are : the obligatory, optional and pragmatic explicitation such as (addition, substitution, recasts and narrowing ( specification).

2. Resorting to some types of explicitation strategy is not quite easy. This is because the explicitation strategy involves very subtle differences in meaning that are difficult to grasp.

3. The translator is not fully aware of the Arabic lexical term and its implications, leading him to fall into the trap of inaccurate lexicalizations, which renders the fidelity of the ST message as being incommunicative.

4. The translator has not entirely been successful in translating some cultural expressions hence, his translations are out of context because he used literal translation in his rendering.

\subsection{Pedagogical Implication of the Study}

Integrating this study, and other similar studies, into the course of Translation teaching in Arabic and English course in Sudanese and other Arab and world universities, this may enhance the students' translational performance; the application of the knowledge of translational techniques and strategies to concrete texts. In other words, the teaching aim of such studies is to enable the student to translate the rebellious lexemes.

\subsection{Recommendations}

In the light of the findings of the current study, it is recommended:

1. The first essential condition of the interpreter is that he must have a very good knowledge of Arabic. Knowledge of Arabic and its grammar is an extremely important factor in interpreting the novel .

2. Promoting translators' awareness of the necessity of reading and understanding the linguistic in general and explicitation strategy in particular

\section{References}

\section{Primary Sources :}

Tayeb Salih's Season of Migration to the North

Secondary Sources

Ali, A. (1983) Word Repetition in the Qur'an - Translating Form or Meaning. Journal of Language and Translation, (Vol.6.(1999)19, 17-34.( Australia).

Ali, M.Y. (1983). The Holy Qur'an: Text, Translation and Commentary (3rd ed., Vols. 1-3). Lahore: Sh. Muhammad Ashraf Publishers.

Al-Haj, Ali Albashir M.(2014).Text Linguistics and Translation. US: CreateSpace Independent Publishing Platform .

Al-Haj, Ali Albashir M.(2014).Semantics. US : CreateSpace Independent Publishing Platform

Alnoor, Abdlrahan Yadi,(201)Tayeb Salih's Season of Migration to the North

Cresswell, S. (1994). Content Analysis: Concepts, Methods and Applications. Nurse Researcher, 4(3), 5-16

Dickins, J., Sandor H. \& Higgins, I. (2002). Thinking Arabic Translation. A Course in Translation Method: Arabic to English. London: Rutledge

Dornyi, Z.(2007)Research Methods in Applied Linguistics. Buffalo: SUNY Pres. [50].

Dweik and Abushakra(2010). Strategies in Translation in Religious Texts . Atlas Global Journal for Studies and Research

https://www.iasj.net/iasj?func=article\&aId=11808

Matthiessen, C.M.I.M. (1999). The Environments of Translation. In Steiner, E. \& Yallop, C. (Eds.) Beyond content. Berlin: de Gruyter

Jimenez-Crespo, M. (2011). "The Future of General Tendencies in Translation: Explicitation in Web Localization", Target, 23:1, pp. 2-25

Khan, M.E.(2008) Approximation of the Meaning of the Holy Quran: A linguistic Analysis. Oxford:

Klaudy, K. \& Károly, K. (2005). Implicitation in Translation: Empirical evidence for operational asymmetry in translation, Across Languages and Cultures, 6 [1]: 13-28

Klaudy, K. (2008). Explicitation. In M.Baker , \& G.Saldanha (eds.) . Routledge's Encyclopedia of Translation Studies (pp.104-108). London: Routledge.

Nida, E. (2002). Contexts in Translating. Amsterdam: John Benjamins Publishing Company.

Taylor, J. R. (2002). Near synonyms as Co-extensive Categories: 'High' and 'tall' revisited. Language Sciences, $25,263-284$.

Vinay, J. P., \& Darbelnet, J. (1958/1995). Comparative stylistics of French and English: A methodology for translation (Vol. 11). John Benjamins Publishing 